\title{
OCUPAÇÕES (IM)PROVÁVEIS: QUE CIDADE DEVÉM?
}

\author{
(IM)PROBABLE OCCUPANCIES: \\ WHAT IS THE CITY BECOMMING? \\ OCUPACIONES (IM) PROBABLE: \\ ¿QUÉ DEBE LA CIUDAD?
}

Elenise Cristina Pires Andrade

\section{RESUMO}

Fios-palavras-gestos em uma intimidade quase exposta. Momentos de produção de imagens que (se) pretendem deslugar: grafites em um muro de escola pública em Feira de Santana e oficinas de fotografias realizadas com alunos do ensino médio também de uma escola pública em Ichu (ambas no sertão baiano). Ações decorrentes do projeto de pesquisa "Cidades (des)enquadradas em imagens: experimentações (atra)versando o conceito de signo" que questiona: o que podem as imagens quando não pretendem explicar, ilustrar, registrar as cidades? Pretender, então, proliferar conexões, provocar a invenção de novas formas de olhar e vivenciar o mundo, a cidade, a produção de conhecimento, a expressão cultural dos artistas e estudantes no lugar das explicações e coerências. Propor, então, que a cidade não seja entendida, sentida, explorada apenas como cenário, mas sim máquina produtora de signos, expressão, conhecimentos. O conceito deleuziano de diagrama busca explorar e potencializar tais produções, pretendendo a desestabilização de uma política da representação para olhar, conhecer e inventar cidades. Provocar (na arte, na vida, na escrita, na educação, em lugar nenhum) rompantes de caos, desconsiderações às classificações e aos julgamentos morais.

PALAVRAS-CHAVE: Fotografias. Filosofia da diferença. Cidade.

\begin{abstract}
Wire-words-gestures in an almost exposed intimacy. Moments of images production that intend to desplace: graffiti in a public school wall in Feira de Santana and photographs of workshops with high school students from a public school in Ichu (both cities in the Bahian backcountry). Actions resulting from the research project "Cities (un)framed within images: experimentations crossing the conception of signs" that asks: What can the images do when they don't want to explain, to illustrate, to remember the cities? Instead of explanations and coherence, we aim to proliferate connections and provoke the invention of new ways of looking and experiment the world, the city, the production of knowledge, the cultural expression of artists and students. We propose that the city is not to be understood and exploited only as a backdrop, but it can be a producer machine of signs, expression, knowledge. The Deleuzian concept of diagram explore and enhance these productions, aiming at destabilization of political representation to look, learn and invent cities. To provoke (in art, life, writing, education, anywhere) chaos outbursts, slights to the ratings and moral judgments.
\end{abstract}

KEYWORDS: Photographs. Philosophy of difference. City. 


\section{RESUMEN}

Alambre-palabras-gestos en una intimidad casi al descubierto. Producir imágenes de los momentos que (si) tienen previsto deslugar: pintada en una pared de la escuela pública en Feira de Santana y fotografías de los talleres con los estudiantes de secundaria también de una escuela pública en Ichu (tanto en las tierras del interior de Bahía). Las acciones resultantes del proyecto de investigación "Ciudades cruzadas de fotografías: ensayos que tratan el concepto de signo" que se pregunta: ¿qué pueden las imágenes cuando quieren explicar, ilustrar, grabar las ciudades? Pretender entonces proliferar las conexiones, hacer que la invención de nuevas formas de ver y experimentar el mundo, la ciudad, la producción de conocimiento, expresión cultural de artistas y estudiantes en lugar de explicaciones y consistencias. Propone, pues, que la ciudad no se entiende, nos sentimos explotados sólo como telón de fondo, pero la producción de la máquina de signos, la expresión, el conocimiento. El concepto de diagrama de búsqueda Deleuziano explorar y mejorar estas producciones, con miras a la desestabilización de la representación política de mirar, aprender e inventar ciudades. Causa (arte, la vida, la escritura, la educación, la nada) estallidos de caos, desaires a las calificaciones y juicios morales.

PALABRAS CLAVE: Fotografía. Filosofía de la diferencia. Ciudad.

\section{Ocupação (im)provável primeira:}

"Momento de repensar rumos e funções, a $28^{\mathrm{a}}$ Bienal entraria para a história como a "Bienal do Vazio". Concebida por Ivo Mesquita e Ana Paula Cohen, a mostra deixou um andar inteiro sem obras, numa metáfora clara da crise conceitual atravessada pelos sistemas expositivos tradicionais. [...] "É ali, no território do suposto vazio, que a intuição e a razão encontram solo propício para fazer emergir as potências da invenção, abrindo múltiplas possibilidades para ser cruzado. Faz um corte, suspendendo o processo voraz de produção e consumo de representações, para problematizar o possível esgotamento dos diversos discursos no território da instituição. O corte aqui quer aguçar a crise da organização, do modelo, do sistema, e não recalcá-los com mais uma exposição" - "É positiva a proposta para a $28^{\text {a }}$ Bienal de São Paulo, que prevê, entre outras coisas, um andar vazio?", "Sim. Temos que enfrentar o horror ao vazio", de Ivo Mesquita, publicado na Folha de S. Paulo em 01 dez. $2007^{1}$.

\section{Ocupação (im)provável segunda:}

Vídeo disponível em 〈https://goo.gl/ctl6gF>. Acesso em: 20 fev. 2016. "Pixadores atacam a $28^{\circ}$ Bienal de São Paulo, 40 jovens invadiram e pixaram o "andar vazio" da Bienal de São Paulo 2008" (enviado em 27 de out de 2008).

\section{Ocupação (im)provável terceira:}

A lei da hospitalidade, a lei formal que governa o conceito geral de hospitalidade, aparece como uma lei paradoxal, perversível ou pervertedora. Ela parece ditar que a hospitalidade absoluta rompe com a lei da hospitalidade como direito ou dever, com o "pacto" da hospitalidade. Em outros termos, a hospitalidade

${ }^{1}$ Fonte: 〈http://goo.gl/W5JUUA >. Acesso em: 20 fev. 2016. 
absoluta exige que eu abra minha casa e não apenas ofereça ao estrangeiro (provido de um nome de família, de um estatuto social do estrangeiro, etc.), mas ao outro absoluto, desconhecido, anônimo, que eu lhe ceda lugar, que eu o deixe vir, que o deixe chegar, e ter um lugar no lugar que ofereço a ele, sem exigir dele nem reciprocidade (a entrada num pacto), nem mesmo seu nome (DERRIDA, p. 23 e p. 25).

\section{(des) ocupar tantas quantas forem ocupáveis...}

Cidades, pixações, vazios, invasões, deslocamentos. Ocupação (im)provável como fenda. Talvez gestos, assim como essa escritapesquisa em experimentação que, pretendemos, nos permita algumas rupturas, em especial, com pensamentos que levem a concretizações, centralidades e determinações seja da ciência, da arte, do tempo, da produção de conhecimento ou do próprio pensamento. Rupturas que Deleuze (2003) e Deleuze \& Guattari (1977) levam ao esgarçamento na intensidade da expressão maquínica, descontinuada, inorgânica na proliferação das séries de coisas, fatos, tempos, palavras. "Rasurar os lugares. Tornar esses lugares estrangeiros de si mesmos: aquilo que é forçado a ser também o deslugar, o intervalo entre aquele lugar e ele mesmo [...]" (OLIVEIRA JÚNIOR, 2013 p. 207). Fissura, riscos, fios que escorrem onde antes eram (seriam?) letras, como na obra Diario intimo, de Maria Lai ${ }^{2}$. Experimentações versadas em risco.

O esforço violento do corpo em direção à experiência é a ampliação e mudança de seus limites. Um certo tipo de intencionalidade do que Anne Hickey-Moody (2013) denominou de pedagogia da afeç̧ão, trata-se da experiência sensível que, primeiramente, é reconfiguração corporal e, depois, uma nova geografia emergente da experiência. Como isso pode acontecer? (AMORIM, 2013, p. 417).

Antonio Carlos Amorim, ao continuar sua reflexão, nos apresenta algumas possibilidades de responder a sua pergunta ao explorar "[...] correlações entre os perceptos e precisamente os devires não humanos do humano" (Amorim, 2013, p. 417) criados nas mais diferentes relações envolvendo os objetos, as ideias e os pensamentos da/na pintura, cinema e literatura. Inspirada no autor - que também se deleita com os conceitos e as ideias da filosofia da diferença -, proponho o questionamento que atraversará esse texto: quais gestos invadiriam as cidades em um devir intensivo provocado por signos a nos provocar e forçar a sentir a diferença; a provocar fendas no movimento maquínico da enunciação nos muros, nas ruas, nas fotografias, nas palavras, disparando forças criativas; a ressoar por uma pedagogia da afecção?

Ressonâncias que continuam com Amorim (2013) quando nos diz que o papel dos signos tensiona as relações entre o visível e o dizível, sendo assim chamado a invadir e perfurar a ideia de enunciação no plano dos estudos de currículo. Roubar esse tensionamento e desejar a potência dessa invasão. Inter-valar. Cavar valas, assim como o vídeo de David Lynch (1968) The Alphabet ${ }^{3}$ me provoca. Afecções em fios-palavras em uma intimidade quase exposta. Imagens que escorrem: a $28^{\mathrm{a}}$ Bienal, o pixo no espaço vazio, a lei da hospitalidade, dois momentos de produção de imagens decorrentes do Projeto de pesquisa

${ }^{2}$ Obra de 1977. Maiores informações em 〈http://goo.gl/I6Stn〉. Acesso em: 10 fev. 2015.

${ }^{3}$ Disponível em <https://goo.gl/SdzUGn>. Acesso em: 02 jun. 2015.

\begin{tabular}{l|l|l|l|l|l|l} 
(C) ETD - Educ. Temat. Digit. & Campinas, SP & v.18 & n.3 & p.651-669 & jul./set. 2016 & ISSN 1676-2592
\end{tabular} 
"Cidades (des)enquadradas em imagens: experimentações (atra)versando o conceito de signo" : um encontro para a produção de grafite nos muros de uma escola pública em Feira de Santana e oficinas de fotografias com alunos do ensino médio em uma escola pública em Ichu, cidades no interior da Bahia. Momentos de experiência sensível com vontade de tensionar: o que podem as imagens quando não pretendem explicar, ilustrar, registrar as cidades?

Propor que a cidade não seja entendida, sentida, explorada apenas como cenário, mas sim máquina produtora de signos, expressão, conhecimentos. "Des-conhecer. Convidar a fechar os olhos e recusar a poderosa investida na produção de sistemas homogêneos de pensamento que atravessam imagens, textos e sons na contemporaneidade" (Dias, Andrade, Oliveira, p. 2011, p. 116) e, para isso, assumir o conceito de diagrama como proposta de exploração das potencialidades intensivas dos/nos signos a nos impelir a explorar uma zona de deslugar. Além de convite ao fechamento dos olhos, também de um encurvar os pilares e os ditames da educação nesse (AR)riscar, esvaziá-la dessa substância educação que quer a tudo entender, explicar, organizar, decifrar, nomear.

Esvaziar para continuar nas possibilidades das dobras, fora/dentro, gesto-corpo-cor em funcionamento para que provoquem tensionamentos de sentidos de escolas/muros/cidades/mundos. Experimentarmos um atraversamento nos pensamentos em educação em um produzir riscos em devir, sempre esboçados, letra-fio. Basbaum (2006) nos apresenta uma interessante reflexão em que o conceito de diagrama emerge como funcionamento na relação de sua obra artística com o público, indicando um "[...] duplo movimento das forças do pensamento e da matéria, como um dispositivo para a produção de transformações" (BASBAUM, 2006, p. 73). Com este artista, trabalhar o diagrama como instrumento:

\begin{abstract}
Ultimamente tenho trabalhado o diagrama como instrumento - empregando-o para abrir e ocupar um tipo de espaço intermediário entre discursos e obra de arte. Há um processo de construção para obtenção deste espaço, aglutinando as palavras e tecendo um espaço dinâmico com linhas e diversos elementos visuais. Sobretudo há o desejo de instaurar, no desenho, índices de ritmo e de pulsação: sem um modelo rítmico adequado, o diagrama não funciona. Sim, pulsação, produção de ressonância, vibração rítmica - é o que garante que o diagrama movimente-se e produza as inscrições necessárias, sem as quais se tornaria uma abstração que não intervém, que não move nenhum espaço e que não ocupa nenhuma região. (BASBAUM, 2010, p. 2, tradução nossa).
\end{abstract}

Pulsação gesto-corpo a-riscado. Signos a emanarem dos gestos e(m) grafites e fotografias. Conexões, contatos, contaminações em movimentos intensivos, como nos propõe Ricardo Basbaum (2006, p. 67) ao pontuar que "Podemos considerar que um diagrama será sempre gerado como dispositivo relacionado ao local de proximidade máxima da experiência [...]”. Deixar-se enlouquecer pela potência criativa do impensável no pensamento, como tantas vezes as crianças, os loucos, os bêbados (se) deixam!

\footnotetext{
${ }^{4}$ Edital CNPq, 043/2013 Ciências Humanas, Sociais e Sociais Aplicadas, processo n ${ }^{\text {o }}$ 409115/2013-4, coordenado por mim.
} 
O silêncio...
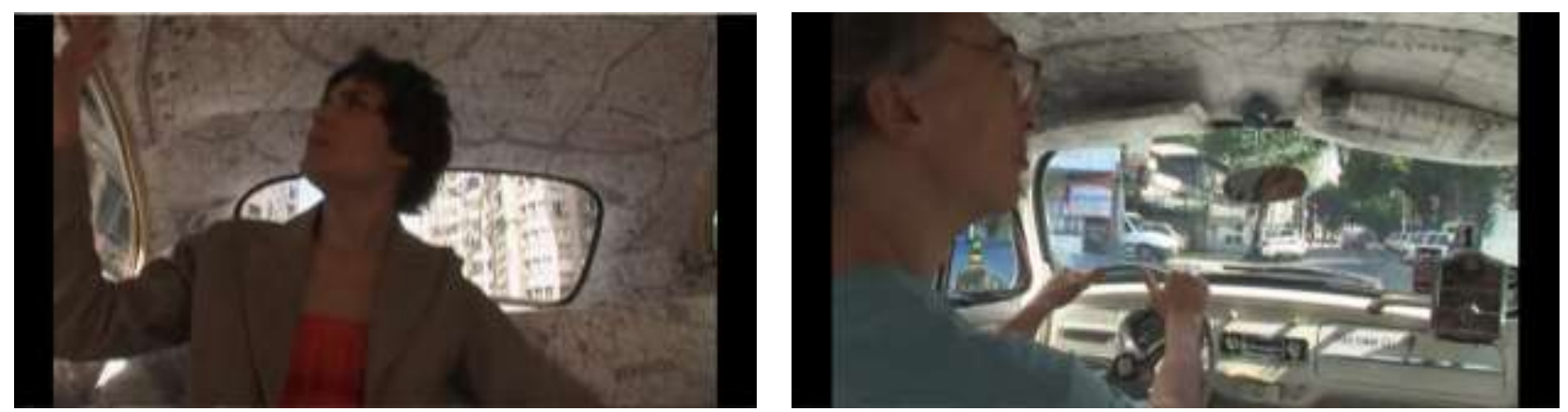

Ela: Nossa! Quantas ruas tem essa cidade?

Ele: Ah! Umas 50 mil. Na verdade, nascem 3 ruas novas por dia. É o que os vereadores ficam fazendo lá na câmara: inventando nome de rua.

\section{O que precede...}

Cidades, ruas, contornos, fotografias, imagens, palavras, fios, conceitos filosóficos, escritas experimentais. Fragmentos potentes. Diálogo a partir de frames e das frases ditas por Ele e Ela em Otávio e as letras ${ }^{5}$ a partir de 8:08 minutos. Grafitar, fotografar e pós produzir as imagens. Gestos potentes que nos ajudam a pensar nos conceitos de signo e diagrama (acompanhando as movimentações de Deleuze) e a desestabilização de uma política da representação para olhar, sentir, explorar, inventar cidades, ruas, escolas, vidas. Afectar. Não perguntar o que esses gestos mostram da/na/com a cidade, mas o que as intensidades e forças que a atravessam e povoam querem nos mostrar... Nossas vontades ressoam pela tentativa da desconstrução, do desvio, da subversão, chamando as sensações - não somente as explicações - junto às discussões realizadas através dessas duas atividades de pesquisa.

Desdobrar, explicar, des-lembrar em uma escritapesquisa, buscando um pensamento com imagens imerso nos movimentos atuais das artes visuais e, numa ação coletiva e plural, desequilibrar fronteiras fixas entre imagem, ficção e realidade; conhecimento, memória e explicação; educação, arte e criação. Não aceitar que as imagens e as palavras/ideias nas/das vozes que habitam esse texto apenas nos mostrem, nos expliquem sensações, conhecimentos, pensamentos sobre algo ou alguém, mas ir em busca de um modo, um funcionamento do gesto entre elas e o aquilo em nós que com elas encontra. Intensidade do instante. Pulsações e intensidades de perturbar o pensamento, continuar o enlouquecimento através do fictício (?) diálogo travado a seguir, quase uma continuação da conversa entre Ele e Ela do filme de Masagão:

Elenise Andrade: Entre ruas nasce-se. Nascem ruas. Nascemos nus e as ruas? Nascem como? Que tempo seria esse do nascimento das ruas? E do nascimento nas ruas? Entre tempos...

${ }^{5}$ Produção cinematográfica dirigida por Marcelo Masagão, 2007.

\begin{tabular}{l|l|l|l|l|l|l} 
(C) ETD-Educ. Temat. Digit. & Campinas, SP & v.18 & n.3 & p.651-669 & jul./set. 2016 & ISSN 1676-2592
\end{tabular}


Tiago Moralles ${ }^{6}$ : Conheço muita rua com nome de gente e pouca gente com nome de rua. Isso quer dizer que se não tivesse tanta gente não teria tanta rua?

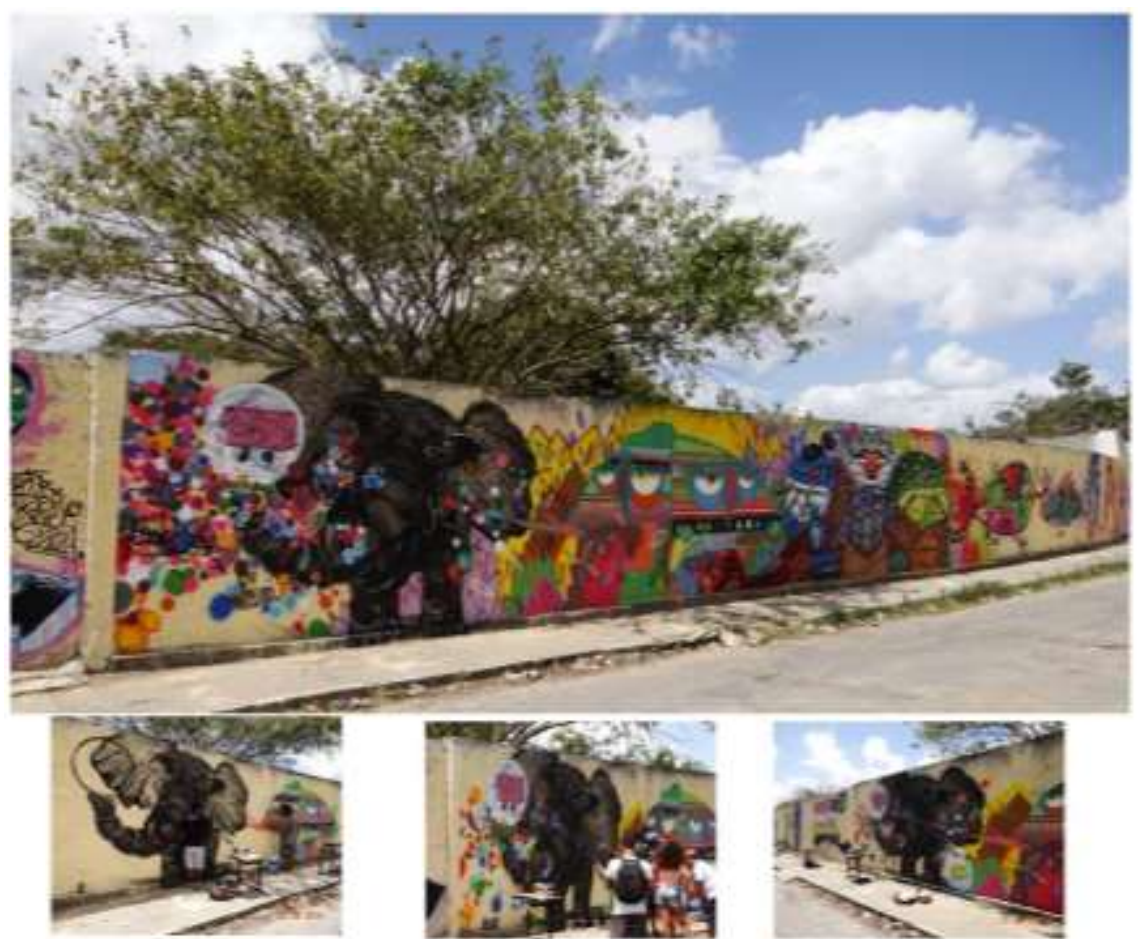

FIGURA 1 - Fotografias do muro externo do Colégio Estadual José Ferreira Pinto durante o $2^{\circ}$ Encontro de Grafitti. Feira de Santana, BA

Fonte: [fotografia de Marcos Barata, 27 e 28/09/2014, arquivo pessoal]
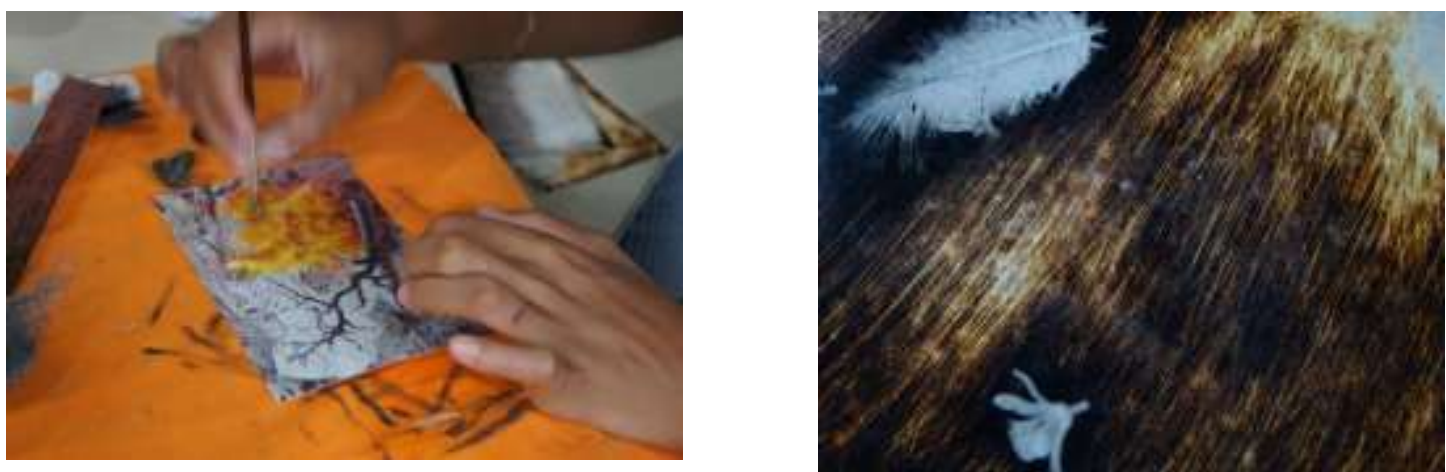

FIGURA 2 - Fotografias produzidas durante Oficina com estudantes do ensino médio do Colégio Estadual Aristides Cedraz (CEACO). Ichu, BA.

Fonte: [26/05/2015, arquivo pessoal]

Isso quer dizer que se não tivesse tanta gente não teria tanta rua?

Não teria?

\footnotetext{
${ }^{6}$ Tiago Moralles, artista que "trabalha como redator pra ganhar dinheiro e como escritor pra perder", paulistano desde 1985. Formado em Comunicação Social. Tem um livro de contos publicado, algumas participações em antologias e um livro de micronarrativas pra sair do forno. Publica regularmente pensamentos no Instagram (@tfmoralles) e textos no blogue <http://goo.gl/5qh5KA>.
}

\begin{tabular}{l|l|l|l|l|l|l} 
(C) ETD -Educ. Temat. Digit. & Campinas, SP & v.18 & n.3 & p.651-669 & jul./set. 2016 & ISSN 1676-2592
\end{tabular}


Arriscarmo-nos com Deleuze e o funcionamento do diagrama quando o filósofo, ao atraversar a obra de Francis Bacon, propõe que o pintor, em seus quadros, desafia a figuração e a narração. Aspectos que, para Deleuze (2007), são efeitos que teimam em invadir os quadros (não somente os de Bacon). Esse desafio desata fios e linhas e forças - o diagrama. Queremos experimentar como esse conceito nos impele a explorar uma movimentação gestocorpo-signos nesses dois momentos de produção de imagens.

Em setembro de 2014 ocorreram três eventos concomitantes: O $2^{\circ}$ Encontro de Grafitti, iniciativa do Coletivo Juvenil $\mathrm{H}_{2} \mathrm{~F}^{7}$, concentrando as atividades pelos muros do Colégio Estadual José Ferreira Pinto. O Museu de Arte Contemporânea Raimundo de Oliveira (MAC) realizou o FeirARTE: expressões urbanas promovendo exposições de artistas feirenses, oficinas de arte e a abertura do TRACEjando por Feira de Santana: pulsões expressivas, evento de cunho acadêmico, promovido pelo grupo de pesquisa Trace, do Departamento de Educação da Universidade Estadual de Feira de Santana (Uefs), focando a ação em uma mesa redonda que contou com estudiosos da arte de rua, predominantemente o grafite, e alguns artistas.

Focaremos, aqui, no $2^{\circ}$ Encontro de Grafitti. Andréa Pinheiro, diretora do colégio, juntamente com sua equipe de gestores e professores, não só possibilitou a enorme tela (paredes do Colégio Estadual Ferreira Pinto) para os artistas como os abrigou durante o final de semana de setembro de 2014 para a realização do Encontro, exprimindo uma outra política que não reconhece fronteiras. Rua-muro-escola. Aluno-muro-gestores. Cores-muro-riscosgrafites. Escutemos as palavras de Andréa:

\begin{abstract}
"Quando nós falávamos do encontro de grafite, muitas pessoas tinham a ideia de que, quem estaria aqui, seriam pessoas pra pichar tudo de preto. Essa é a primeira ideia que alguém que não tem conhecimento pensa do grafite. E quando eles [os artistas] fizeram as oficinas, que depois começaram a produzir a arte, colorir o muro, eles viram que o grafite é uma arte. Só que uma arte urbana, né? Ela não tá numa galeria, não tem preço. Então o preço é a beleza que tem aqui a nossa escola hoje".
\end{abstract}

Essa fala nos ajuda a pensar na pergunta de Tiago Moralles. Ruas, existências, gentes, riscos que provocam a beleza dos muros. Des-fiar- Desafiar. Diagramar. Ritmos deslocados de uma organi-cidade a pulsarem em outros pensamentos em relação ao movimento de produção e divulgação de conhecimentos. "O que me interessa é o modo como, traçando linhas, dispondo palavras ou repartindo superfícies, desenham-se também partilhas do espaço comum" (RANCIÈRE, 2012, p. 101). Formas de partilha que envolvem uma amplitude

\footnotetext{
${ }^{7} \mathrm{O}$ evento contou com artistas de várias partes do Brasil e alguns do exterior (mais imagens e informações encontram-se disponíveis em: 〈https://goo.gl/ER6Cjn>, objetivando fortalecer a arte do grafite na cidade e colocar o evento na agenda cultural/cena de Feira de Santana e região. O coletivo H2F, composto de jovens, busca uma intervenção mais ampla a partir de ações culturais que transformem a cidade e atinjam outros jovens por meio da cultura hip hop, do grafite, da poesia, da literatura, e das linguagens diversas. Esse grupo tem a percepção inicial de que a cultura não acontece apenas em torno da música do hip hop, mas principalmente em sua contribuição social nas comunidades em que se encontram presentes, trazendo à tona discussões sobre a realidade social da população.
} 
"sensível do comum da comunidade, das formas de sua visibilidade e de sua disposição" onde "se coloca a questão da relação estética/política" (Rancière, 2009, p. 26) - entendendo o estético como um modo de articulação entre maneiras de fazer, formas de visibilidade e pensabilidade dessas maneiras e suas relações, implicando uma ideia de efetividade do pensamento, conclui o filósofo francês.

Inspirada por tais modalidades de (des)acertos expressivos realizamos, entre 2014 e 2015, três oficinas no Colégio Estadual Aristides Cedraz (CEACO), com aproximadamente vinte estudantes do segundo ano do ensino médio, nas quais os provocamos, com o auxílio de várias obras artísticas a eles apresentadas, a in-ventarem imagens da cidade que transgredissem a política da representação, para, então, possibilitarem a imersão em uma lógica das sensações, pulsações de lugares recortados pelo instante de um clique sob o olhar deslocado do fotógrafo (ALMEIDA, 2015).

Um questionamento atravessou os encontros/oficinas: Que Ichu (des)enquadra em mim? Como fotografar tal pergunta, nos inquietava os estudantes? Fotografem a cidade de um outro modo, intensifiquem uma Ichu que, comumente, não podemos (conseguimos?) ver. Conjuntamente a essa perturbação, criamos um grupo no whatsapp para continuarmos as conversas sobre/com as imagens, do qual trazemos algumas falas que acompanharam a apresentação das fotografias no grupo. Após muitas fotos reveladas e conversadas fizemos um último encontro em 2015 com a participação de Alik Wunder no qual propusemos experimentações de processos de pós-produção através de montagens, sobreposições, raspagens, recortes, colagens e produção de novas fotografias-fragmentos (WUNDER; ROMAGUERA (2013, 2014). Imagens que não mais remetem a lugar algum, a uma representação de um real, mas a lugares e existências nas próprias imagens...

12 de mai 21:05 - Edivan: Achei essa foto fantástica, Eduarda

12 de mai 21:05 - Edivan: desenquadrou o CEACO... 12 de mai 21:09 - Edivan: a beleza da arte está na invenção...

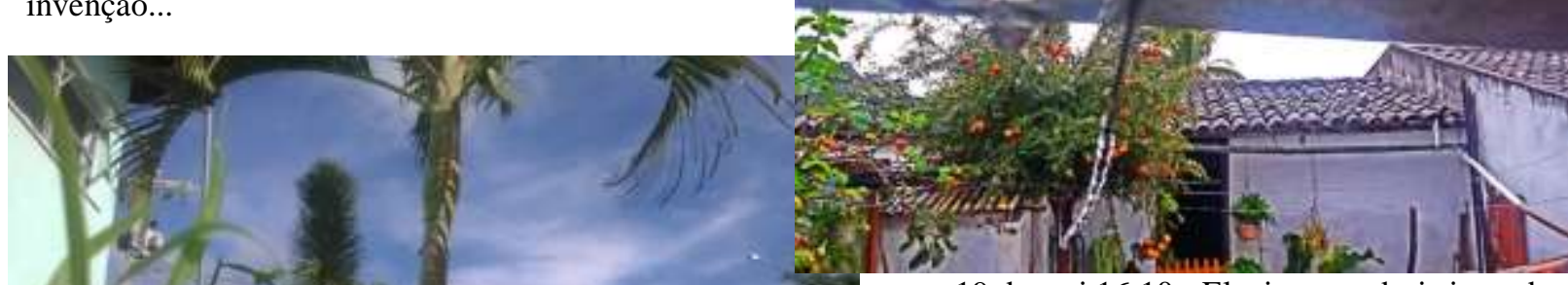

19 de mai 16:10 - Elenise: vcs desistiram de desenquadrar fotos com pessoas? kkk 19 de mai 18:59 - Ceaco Wesley: Eu tenho fotos desenquadrada com pessoas

FIGURA 3 - Fotografias produzidas pelos estudantes do ensino médio do Colégio Estadual Aristides Cedraz (CEACO). Ichu, BA.

Fonte: [maio de 2015, arquivo pessoal] 

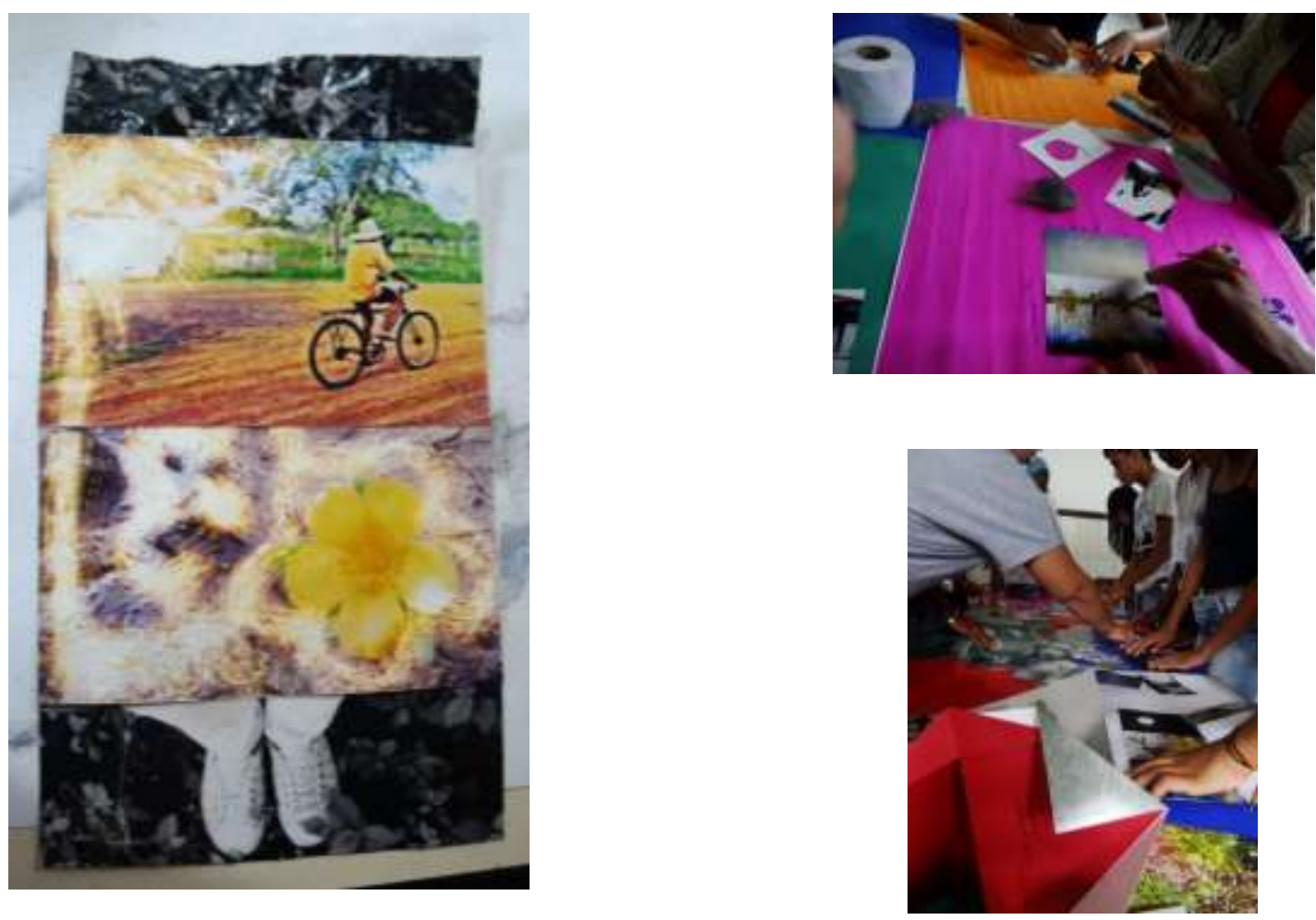

FIGURA 4 - Fotografias produzidas durante Oficina com estudantes do ensino médio do Colégio Estadual Aristides Cedraz (CEACO). Ichu, BA.

Fonte: [26/05/2015, arquivo pessoal] 


\section{Ocupações (im)prováveis: que cidade devém?}

\section{o esporro ${ }^{8}$}

Escrever com imagens é tirar as letras do mundo pra deixar as pessoas olhando, tentando entender, tentando achar palavras.

(Tiago Moralles)

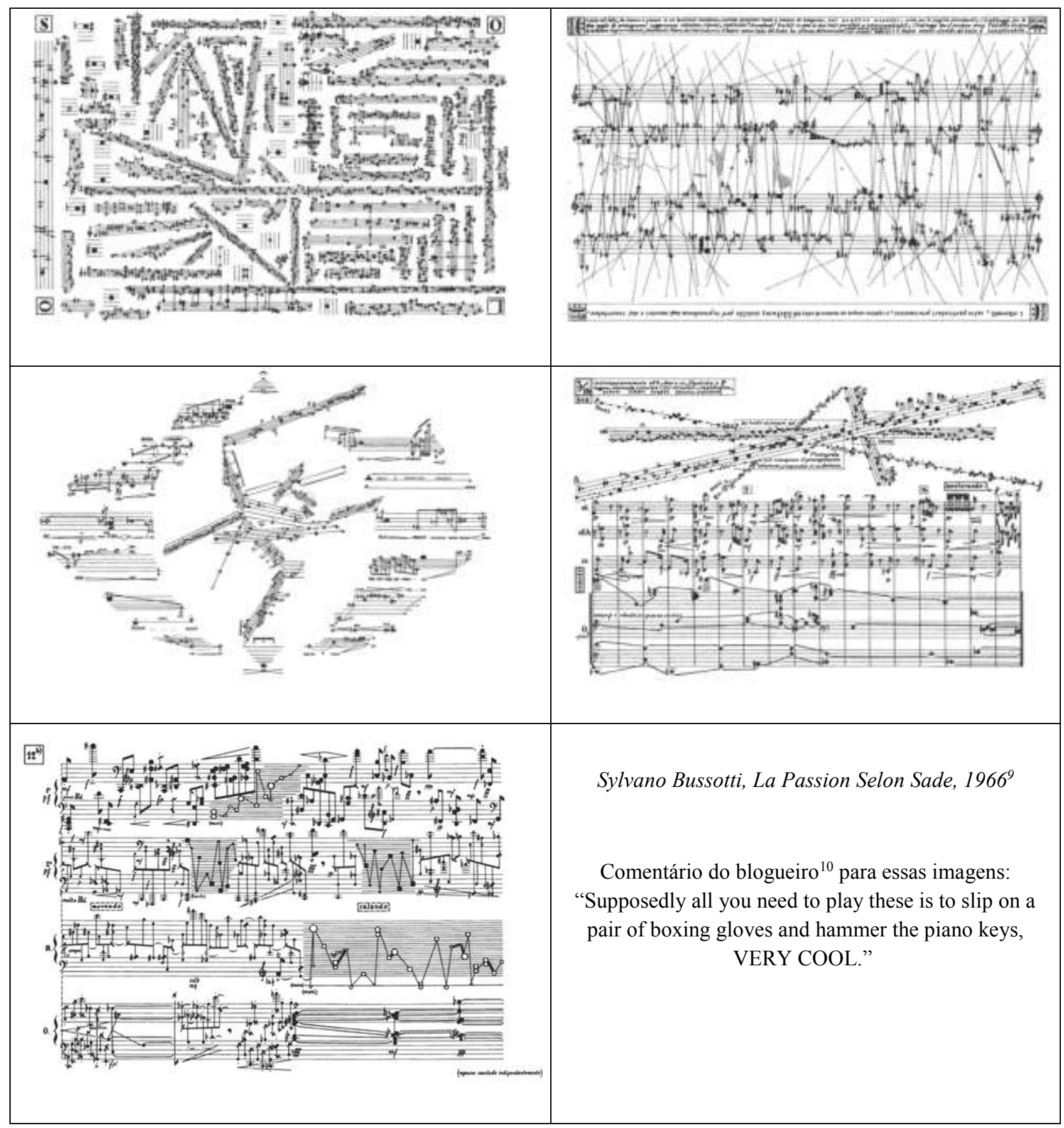

${ }^{8}$ O silêncio que precede o esporro é o título do CD de O Rappa!, de 2003.

${ }^{9}$ Fonte das imagens citada no blog: $<$ http://goo.gl/hDofUT $>$. Acesso em: 18 fev. 2016.

${ }^{10}$ Fonte: <http://goo.gl/49Cxqi $>$. Post publicado em 04 de agosto de 2014. Acesso em: 18 fev. 2016.

\begin{tabular}{l|l|l|l|l|l|l} 
(C) ETD -Educ. Temat. Digit. & Campinas, SP & v.18 & n.3 & p.651-669 & jul./set. 2016 & ISSN 1676-2592
\end{tabular}


Tentar achar palavras. Tentar achar as notas (ou não querem ser achadas, porque não pretendem ser passíveis de representação e uma compreensão?) Tentar "tocar piano com luvas de boxe"? Tentar tirar as letras do mundo? Tensionar, talvez, assim como nos invade Bussoti, com suas linhas que se prolongam das notas e da pauta, cruzamentos (im)pensáveis, espaços que extravasam os espaços da pauta; (im)possibilidades de notação musical. Very cool! (so cool quanto o desenho de Clarinha!)

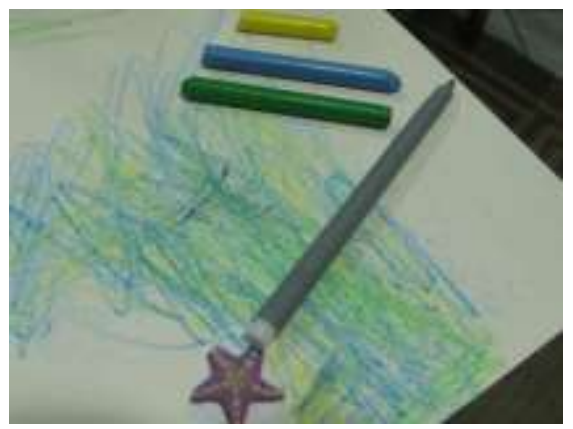

FIGURA 5 - Fotografia de Kaluana do desenho de Clarinha postado no facebook.

Fonte: [postagem no facebook realizada em 13/01/15].

Extravasar as cores, arriscar no risco, ritmos impensáveis nos propõe Clarinha “Mamãe, acabei de fazer a água do Brasil!". "É mesmo?”, perguntou a mãe, continuando a indagar: "e como se faz água do Brasil?". Clarinha, obviamente, responde: "É só misturar todas as cores!". Água cotidiana que se desprende de significados e representações. Escapa de uma figuração no pensamento. Very cool. Ex capas a enveloparem as linearidades necessárias para uma recognição. Talvez aceitar a ideia e colocar as luvas de boxe para tocar a peça ao piano. Águas e paixões em versos e cores que abalam e desenquadram os cotidianos, investindo-os de uma vontade de abrirem-se à força e afetação dos signos.

Rabiscos em muros fabricam e inventam cidades. Fricção com palha de aço e umedecer a fotografia também as fabricam/inventam. Destituir a obviedade das explicações (sejam conceituais, sensoriais, comunicacionais, colocando em funcionamento o diagrama, diferenciando-o do esquema, a modo de re-velar

\begin{abstract}
Para que o diagrama funcione, para que ele seja diferente de um simples esquema, é preciso que ele revele o sentido das suas singularidades. E é porque o diagrama está sempre na interface do actual e do virtual que ele pode assegurar a passagem de um a outro por uma maquinaria que é a alma do diagrama. Essa maquinaria não está lá para representar objetos, mas para produzir, no real, uma actualização das suas componentes virtuais, revelar ao mundo sensível uma face inédita do objeto. (GODINHO, 2013, p. 141)
\end{abstract}

Riscos iniciais no muro que, não necessariamente, se transformarão em algo na imagem grafitada. Quantas vezes, acompanhando os artistas, queríamos adivinhar, pelos traços iniciais, sem cores, o que apareceria na tela-muro? Depois de tantas 'decepções', desistimos, e investimos na invenção do olho-mão. Encontros (im)pensáveis brotando dos movimentos do artista. Don Guto, artista feirense, riscou, arriscou e vermelhou a cena com olhos abertos-fechados a nos espiar. Ex pios silenciosos. É precisamente essa nossa vontade em ter o controle do que veremos, sentiremos, saberemos, pensaremos que se pretende 
subverter em minúsculas partículas de spray para invadir, com esse funcionamento, nossas vontades em relação à pesquisa $\mathrm{e}(\mathrm{m})$ educação.

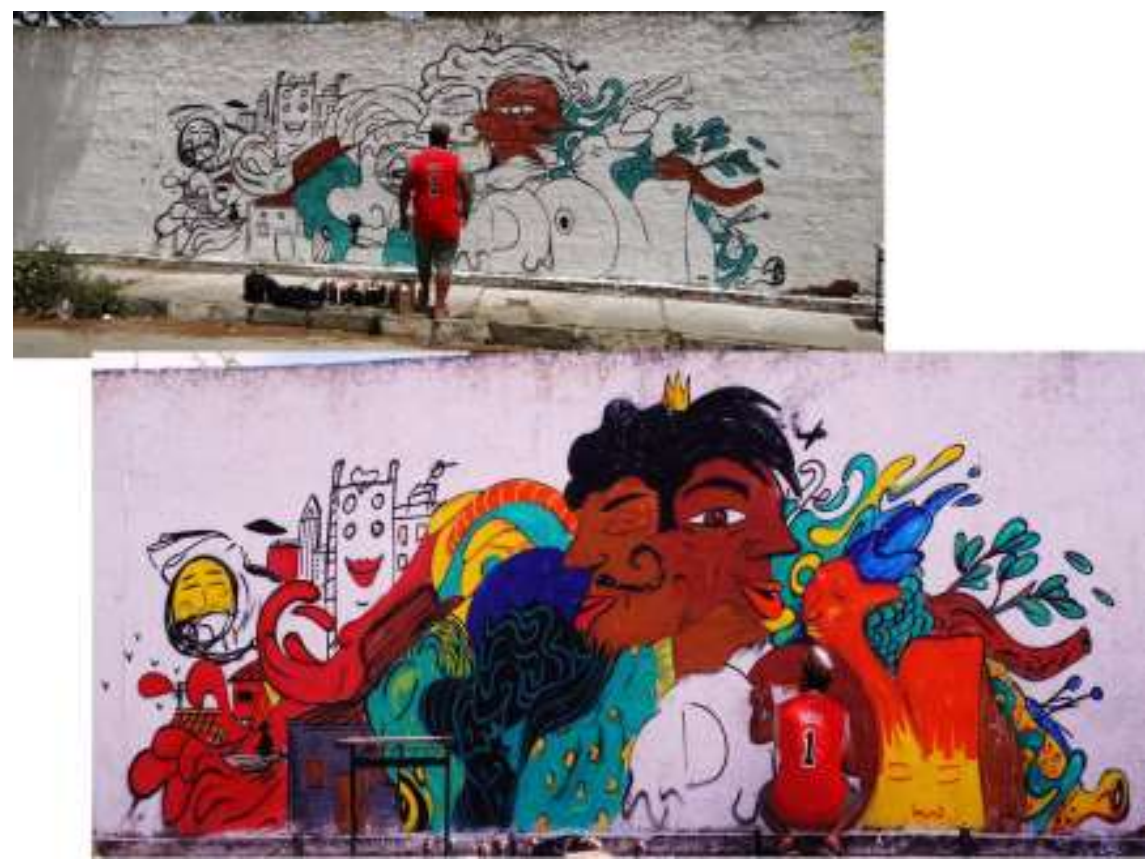

FIGURA 6 - Fotografias do muro externo do Colégio Estadual José Ferreira Pinto durante o $2^{\circ}$ Encontro de Grafitti. Don Guto no momento de sua arte. Feira de Santana, BA

Fonte: [fotografia de Milena Rodrigues, 27/09/2014, arquivo pessoal]

O olho que (não) fala. A boca que (não) vê. Vermelhos... Pois como coloca Ana Godinho (2013, p. 136), "Veremos, na Lógica da Sensação, que o problema é ter um olho impossível. Pensar sentindo, sim, mas com olhos e ouvidos impossíveis". Assim, cabe-nos investigar quais seriam as potências e as forças dessa impossibilidade ao afectar a educação, de que maneira um cotidiano que (se) experimenta no AR-riscar afecta o pensamento na/com a educação. Cabe-nos perturbar...

Cotidiano perturbador... Mas não seriam as perturbações gestos de um cotidiano vivo e(m) experiência? Ruas, muros, cores, cidades in-ventadas, out-ventadas, arriscadas na expulsão de uma necessidade de explicação e (re)cognição dos limites olhos-tato-ouvidosmuros-pensamentos. Estar aberto aos pequenos e delicados gestos, quase (in)visíveis. Nem mundo táctil-ótico, nem mundo ótico puro", diz Deleuze (2007) sobre Bacon "Ao contrário,

11 Deleuze (2007), quando tece relações e (des)conexões entre as geometrias, as sensações, as cores e as luminosidades das escolas de pintura, nos joga (e a Bacon) em direção aos egípcios e às suas superfícies planas, à forma e ao conteúdo como dimensões igualmente próximas de um mesmo plano. Extraindo de cada época sua singularidade, Deleuze dirá então que os gregos, ao distinguirem os planos, inventando uma perspectiva, contribuíram para o que ele designa como representação clássica, que tem "como objeto o acidente, mas [...] o apreende em uma organização ótica que faz dele algo bem fundado (fenômeno) ou uma 'manifestação' da essência" (DELEUZE, 2007, p. 126, grifos do autor). Nesses atravessamentos de contornos e cores e narrativas e figurações, Deleuze versa sobre dois planos que se cruzam: o ótico e o tátil. O movimento que quer se opor à representação clássica se daria então em duas direções opostas: "Ou a exposição de um espaço ótico puro, que se liberta de suas referências rumo a uma tatilidade mesmo que subordinada [...] ou, ao contrário, a imposição de um espaço manual violento que se revolta e abala a subordinação" (DELEUZE, 2007, p. 127-128, grifos do autor), e ambas parecem se encarnar na arte bizantina e na arte bárbara ou gótica, onde essa aparente oposição pode entrar em outras combinações ou correlações novas.

\begin{tabular}{l|l|l|l|l|l|l} 
(C) ETD -Educ. Temat. Digit. & Campinas, SP & v.18 & n.3 & p.651-669 & jul./set. 2016 & ISSN $1676-2592$
\end{tabular}


ele os atravessa, ele os subverte ou os confunde. O diagrama manual irrompe como uma zona de confusão, de limpeza, que deve desfazer ao mesmo tempo as coordenadas óticas e as conexões tácteis" (DELEUZE, 2007, p. 136). Confusão e limpeza que Clarinha nos brinda com as cores desenhadas e sentidas da água. Perfuração. "Estudando as audiovisualidades, tendo Gilles Deleuze como intercessor, as intensidades são o mote das linhas de aprendizado com os signos sensíveis, redescobrindo o tempo, restituindo-o no meio do tempo perdido" (AMORIM, 2013, p. 414). Instantes mínimos no spray, na fricção dos fios da palha de aço que possibilitam irromper outras luminosidades!
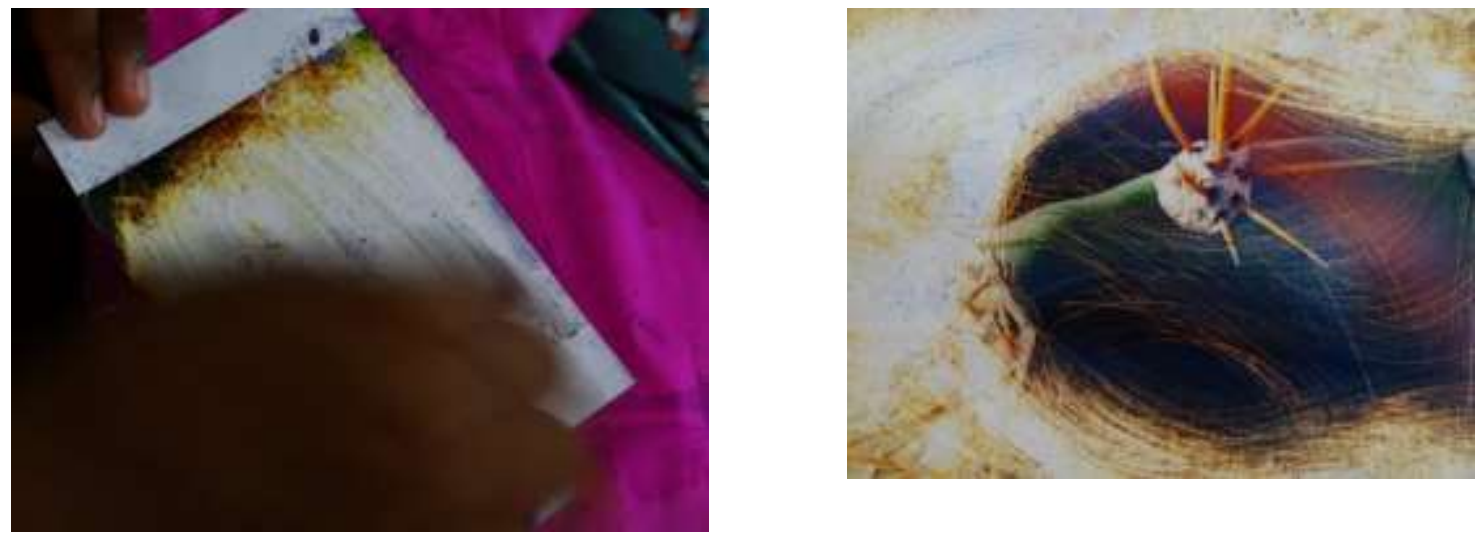

FIGURA 7 - Fotografias produzidas durante Oficina com estudantes do ensino médio do Colégio Estadual Aristides Cedraz (CEACO). Ichu, BA.

Fonte: [26/05/2015, arquivo pessoal]

Cotidianos e lugares são ficcionados-criados em fotografias [de Ichu] que provocam múltiplos sentidos na busca do irrepresentável, do irrepreensível, imagens que não pretendem capturar/significar o real, mas provocar/expressar outras sensações, desencadeando-revelando pontos de vista inesperados, (des)enquadramentos que criam efeitos-sensações-sentidos diversos, produzindo visibilidades que resistem e escapam às convenções e aos clichês que marcam-delimitam nosso olhar nos/sobre os cotidianos vividos, transgredindo o mero registro (ALMEIDA, 2015)

Artistas grafiteiros desobstruindo fluxos de cores que se alongam até os muros da escola pública em um bairro longe/perto, já que abriga a universidade e localiza-se distante do centro da cidade, o conjunto Feira VI. Nas palavras de Kbça Grafitti, um dos artistas organizadores: "O Feira VI é como se fosse uma passarela entre dois mundos: a universidade e vários bairros periféricos que estão ali ao redor." Essa interessante localização do colégio, continua o artista, foi uma das principais causas para sua escolha como palco para o evento: "Uma abertura a mais no lance ${ }^{12}$ da Uefs, a gente nunca conseguiu fazer algumas coisas dentro da Uefs, então a gente achou que seria viável fazer esse lance no feira VI, no Ferreira Pinto, porque aí então poderia, tipo, abrir os olhos da reitoria e de toda galera acadêmica que por ali passava."

Desavisar o que se pretende como coerente para os campos da (re)cognição roubando o funcionamento do artista, "uma abertura a mais no lance da Uefs", ao nos colocarmos por

\footnotetext{
${ }^{12}$ Queremos aqui esclarecer que mantivemos algumas expressões na fala dos artistas grafiteiros, já que são expressões presentes em seus modos de existência e de resistência às agressões e preconceitos que sofrem.
} 
entre muros, ruas, riscos e cores da educação. Gesto-rabisco a se intensificar na expressão dos signos que irrompem dos gestos; que se coagula na potência do intensivo; que delira ao experimentar novas texturas sensíveis - olhos e ouvidos impossíveis. "Resiste-se e, nesse instante, conserva-se; fazem-se as marcas como uma espécie de diagrama, vê-se com um certo olho aparecer possibilidades de factos de todos os tipos" (Godinho, 2013, p. 139), tais como: olhar para um muro de escola e não entender o que encontra, passear pelas ruas de um bairro e não distinguir as utilidades dos rabiscos, raspar fotografias e não ter ideia do que vai acontecer, nem para quê tal gesto serve, tentar tocar piano com luvas de boxe. "O diagrama faz germinar. Desterritorializa e desterritorializa-se na sua potência absoluta. É um devir" (GODINHO, 2013, p. 141).

Propor, com esse funcionamento deslizante/desterritorializante, um esvaziamento dos corredores, salas de aula, giz, quadro, pincel, sinal sonoro entre as aulas, cadernos, memorizações, ruas, muros, fotografias, gentes. Chamar o susto, o imponderável, os professores, os alunos, a gestão escolar a inventar outros tempos e espaços de criação, linhas rasuradas e descentradas. Diagramar o pensarescreverpesquisar educação. Propor esse pintar sem pincel, mas com sprays das minúsculas partículas coloridas que aderem aos sulcos dos muros; esse desphotografar, já que ao riscar as fotos a luz irrompe, luz outra. Espaço hifeno e intenso de encontro entre olhos e mãos, retina e pele, tato e visão; propor, como diz Basbaum (2006, p. 88), “[...] passagens entre eles, criando territórios atravessados pelo ritmo fluido de relações, inter-relações e relacionamentos - incluindo aí forças de tração, repulsão, vizinhança, fragmentação, encadeamento, agrupamento, deslocamento, localização, etc.”.

Durante um final de semana os artistas inundaram, com suas linhas e contornos, as paredes da escola. Partilhas outras. Sensibilidades afloradas pelas rugosidades dos muros, no tato dos olhares, na visão da pele. Durante três encontros, alunos do ensino médio fizeram vislumbrar outras flores, outros sertões, nem sempre tão certos assim da seca, da devastação. Mãos que enxergam. Olhos que tateiam. Suspender uma vontade de explicar as fronteiras, os limites dentro-fora, mãos-olhos. Com-vidar Sébastien Del Grosso e sua obra The sketches inside me II ${ }^{13}$. Inside me, outside me. Esboços (s)em arte final. É preciso possibilitar um gesto entre os planos políticos e estéticos quando nos colocamos a pesquisar escrever educação. Imagens de um suposto mundo áspero a nos convidar ao olhar com as mãos, ao tatear com os olhos (im)possibilidades em decifrar o significado, (des)conexões entre os desenhos. Devir em desvario. Acontecimento vital no ar-riscar.

${ }^{13}$ Disponível em: 〈https://goo.gl/A540XF〉. Acesso em: 17 mar. 2015. 


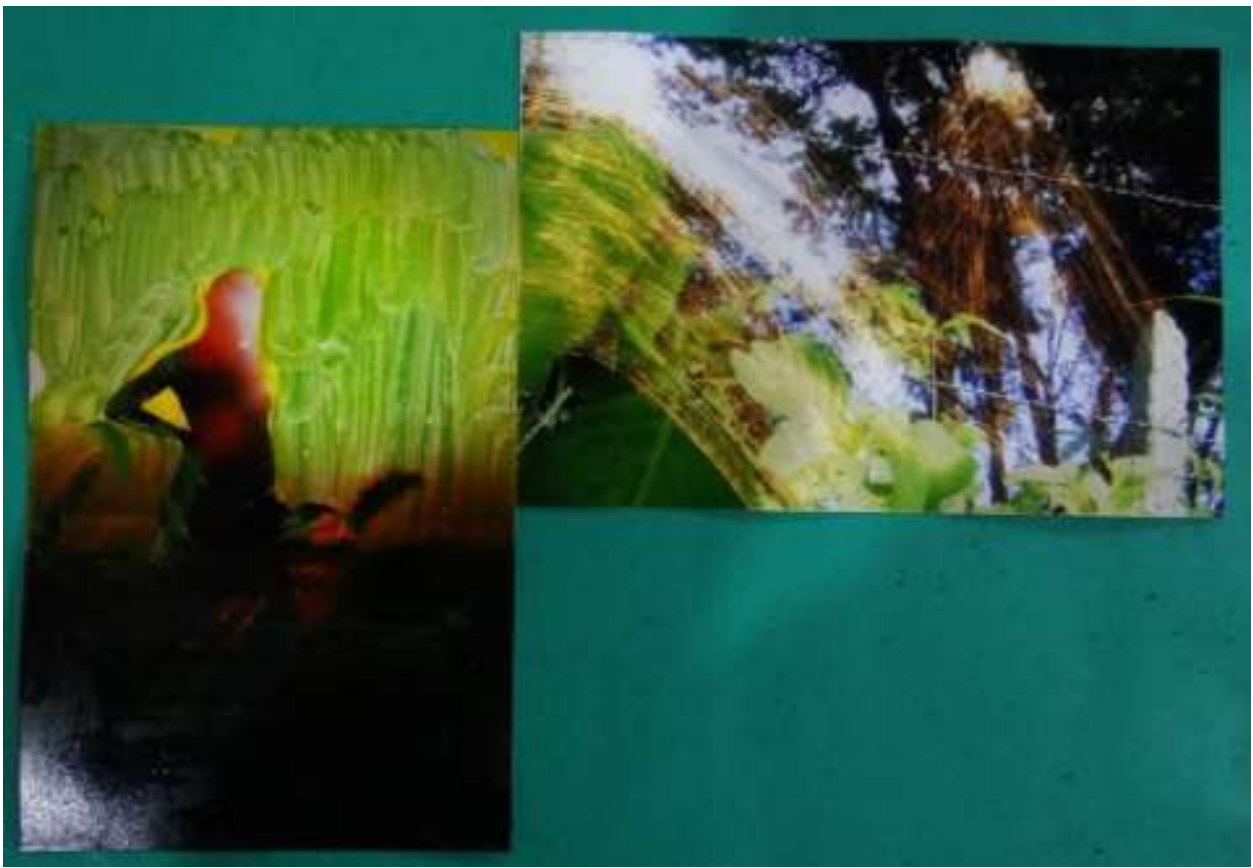

FIGURA 8 - Fotografias produzidas durante Oficina com estudantes do ensino médio do Colégio Estadual Aristides Cedraz (CEACO). Ichu, BA.

Fonte: [26/05/2015, arquivo pessoal]
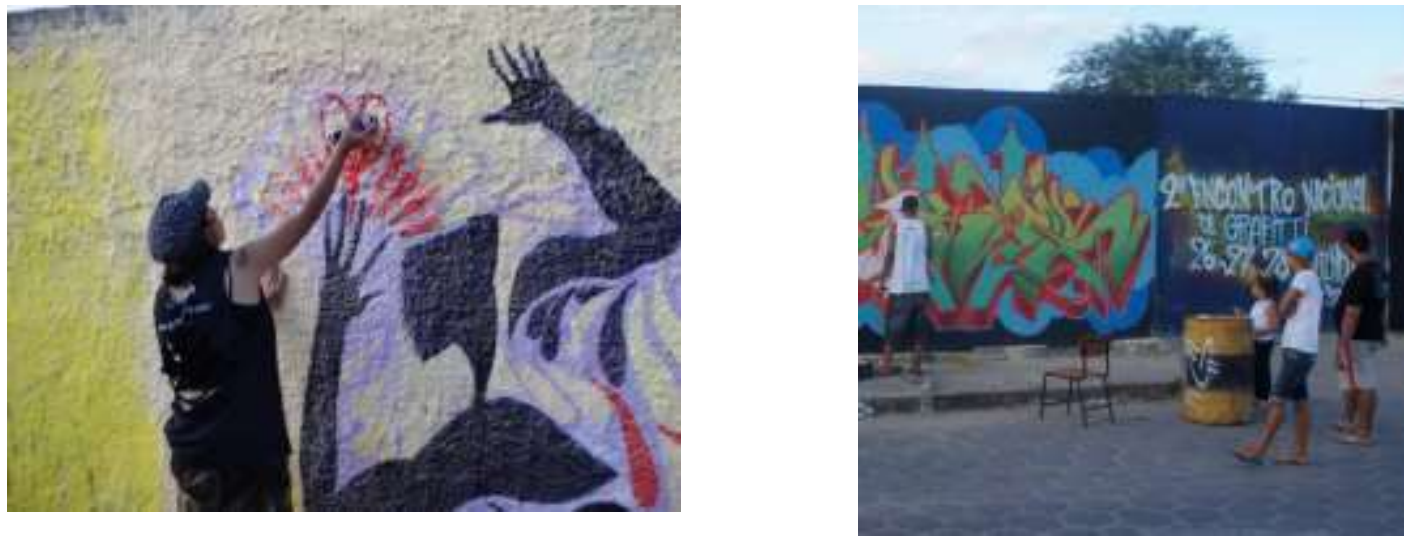

FIGURA 9 - Fotografias do muro externo do Colégio Estadual José Ferreira Pinto durante o $2^{\circ}$ Encontro de Grafitti. Feira de Santana, BA

Fonte: [27/09/2014, arquivo pessoal]

Gestos, cores, riscos, letras. Que cidade é essa, por vir? Que afectos os signos liberam? Que educações essas maquinações (im)possibilitam? Muros, ruas, sentidos em transe, em movimento, fragmentos em devir. Cidade do gesto mínimo, indizível mas não invisível. Des-narrar uma cidade através desses gestos, expulsando uma tentativa de narração, explicação, ilustração. Perfurar, percorrer espaços não limitados em tempos (s)em contagem. A lentidão dos fios, das linhas, dos traçados, uma permanência efêmera no/do contato com uma vontade de esvaziamento da representação. 
Arriscar arrastar o 'pensar a arte' com Deleuze e movimentar os devires das/nas articulações com a experiência estética, um experimento no funcionamento maquínico de um des-narrar, a função K que Deleuze e Guattari (1977) dizem sobre a literatura de Kafka. A potência do diagrama no emergir dessas forças construindo uma pesquisa-em-experimentação que se contamina pela virulência do impensado no pensamento. O'Sullivan (2009) nos apresenta uma interessante proposta de que a arte não seria entendida como um conhecimento, ela não seria "útil" (aspas do autor) nesse sentido. "Arte, me parece, deve ser melhor entendida como um evento que interrompe o pensamento - que quebra a informação (O’SULLIVAN, 2009, p. 250, tradução nossa).

Junto a essas vontades foi que pretendemos esvaziar um sentido e um conhecimento pronto da cidade (Ichu? Feira de Santana?) com os grafites e as pós-produções das fotografias. Desdobramentos, invaginações. Cenários oníricos? Christopher Nolan, na produção cinematográfica A Origem (2010), além de nos presentear com um fabuloso roteiro e direção, nos dobra através de movimentos que, provavelmente, não tínhamos imaginado querer dobrar-se e, que, no entanto, insistem num rodopio vertiginoso. Dobras em deslembranças, como nos nossos sonhos. Deslugares... Seria um movimento des-narrativo? Uma fenda na linearidade do conhecimento acerca do espaço e do tempo? Acordamos tendo a certeza da sensação do giro e não em girar 'verdadeiramente'. Mas, onde estaria (se é que ela existe) a verdade da sensação do giro? No movimento? No deslocamento? No intervalo suspenso dormir-acordar? No gesto ínfimo das linhas?

[...] meu foco será tanto nos meios do cinema para promover encontros com o
espaço-lugar quanto nas potências de um filme - tomado como obra de arte - para
abrir a experiência da paisagem cinematográfica para o sobre que nela desaba
quando a paisagem é atravessada por certos tipos de imagens que arrastam os
sentidos do que ali é "fotografado" - o pensamento? as sensações? - para as
margens dos sentidos de sobra, criação e testemunho, ao mesmo tempo que
continuam a ser mobilizados os sentidos de representação e intervalo. Não há
superação ou negação de um sentido por outro, mas rasuras, estranhamentos,
oscilações, misturas (OLIVEIRA JR, 2015, p. 320)

Roubar de Wenceslao Oliveira Jr a potência criativa desse deslugar, fenda, oscilação (que o autor explora pra falar do filme Acidente, de Cao Guimarães e Pablo Lobato) que nos afecta e, por que não, nos interrompe desse tal conhecimento e nos provoca à dobra do fora pelas sensações inesperadas, impensadas? Ao comentar mais detalhadamente sobre Acidente, uma obra belíssima, Oliveira Jr. conecta-se ao conceito de "pequenas percepções" (Gil, 2005), que atuariam "[...] nos/através dos corpos-imagens e sons esvaziados da lógica informativa, inseridos nos paradoxos das precariedades dos sentidos e sem sentidos que dali vazam, escorrem e esburacam a paisagem (e a significação estável) que buscava se estabelecer" (2015, p. 327). 


\title{
O silêncio que precede o esporro...
}

Kbça Grafitti, Tiago Moralles, Banksy. Feira de Santana, São Paulo e Dismaland Park/Londres. Linhas, cores, escorregões, fendas, invasões, interrupções, coagulações. Impensado, improvável, uma tradução da chuva?

Não somente escorrer e esburacar uma paisagem de significação estável que (se) buscava estabelecer, mas também compor deslugares (s)em fios, rabiscos, luzes, ruas, cidades, educações. Uma pedagogia da afecção?

\begin{abstract}
"Os alunos querem, agora, eles mesmos realizar isso daqui, porque eles acham que é possível fazer, né? [...] E eles querem que isso aqui perpetue. Alguns dias atrás, eles estavam perguntando: professora, isso aqui vai deixar de existir, alguém vem aqui e tirar isso? Eu disse 'Não, isso aqui não vai deixar de existir. Isso aqui vai durar o tempo que ela aguentar nas paredes, né! Nós não vamos tirar."' (Professora de história do Colégio José Ferreira Pinto, Maria Manoela.)
\end{abstract}

\begin{tabular}{|l|l|l|}
\hline Tiago Moralles: "Quando a vida \\
passa mais devagar, estamos \\
aproveitando os intervalos entre \\
uma importância e outra." nos diz \\
@tfmoralles com essa imagem no \\
instagram
\end{tabular}

(des) ocupar tantas cidades? Muros? Kbças? Paredes? Mundos? Quantas forem ocupáveis...

\footnotetext{
${ }^{14}$ Imagem postada em 17/01/2016.
} 


\section{REFERÊNCIAS}

ALMEIDA, Edivan Carneiro de. Que Ichu (des)enquadra em mim? Alegrar, Curitiba, PR, n. 16. 2015. Disponível em: 〈http://goo.gl/qkmI1Z〉. Acesso em: 18 fev. 2016. ISSN 1808-5148.

AMORIM, Antonio Carlos Rodrigues de. n-imagens. In: CAMARGO, Maria Rosa; LEITE, César Donizetti; CHALUH, Laura (Orgs.) Linguagens e imagens: educação e políticas de subjetivação. Petrópolis: De Petrus et Alii, 2014.

AMORIM, Antonio Carlos Rodrigues de. Três crianças a compor um plano para o currículo. Currículo sem Fronteiras, Rio de Janeiro, RJ, v. 13, n. 03, p. 411-426. set./dez. 2013. Disponível em: 〈http://goo.gl/G2Uhfl〉. Acesso em: 31 mar. 2016. ISSN 1645-1384.

BASBAUM, Ricardo. Diagramação e processos de transformação. In: CRUZ, Jorge (Org.). Gilles Deleuze: sentidos e expressões. Rio de Janeiro: Ciência Moderna, 2006.

BASBAUM, Ricardo. Sur, Sur, Sur, Sur... comme diagramme: carte + marque. Multitudes, França, v. 04, n. 43, p. 24-27. 2010. Disponível em: 〈http://goo.gl/vtMVgG〉. Acesso em: 20 fev. 2016.

COUTO, Mia. Tradutor de chuvas. Lisboa: Editorial Caminho, 2011. Disponível em: <http://goo.gl/q7DNSE>. Acesso em: 20 fev. 2016.

DELEUZE, Gilles. Crítica e clínica. Tradução de Peter Pál Pelbart. São Paulo: 34, 2004.

DELEUZE, Gilles. Francis Bacon. Lógica da Sensação. Tradução de Roberto Machado et al. Rio de Janeiro: Zahar, 2007. Disponível em: 〈http://goo.gl/HHGHNW〉. Acesso em: 31 mar. 2016.

DELEUZE, Gilles. Lógica do sentido. São Paulo: Perspectiva, 2003.

DELEUZE, Gilles; GUATTARI, Felix. Kafka por uma literatura menor. Tradução de Júlio Castañon Guimarães. Rio de Janeiro: Imago, 1977.

DERRIDA, Jacques. Anne Dufourmantelle convida Jacques Derrida a falar da hospitalidade. Tradução de Antonio Romane. São Paulo: Escuta, 2003.

DIAS, Suzana Oliveira; ANDRADE, Elenise Cristina Pires de; AMORIM, Antonio Carlos Rodrigues de. I'm wandering round and round, nowhere to go. In: DIAS, Suzana Oliveira; ANDRADE, Elenise Cristina Pires de; AMORIM, Antonio Carlos Rodrigues de (Orgs.) MultiTÃ O: experimentações, limites, disjunções, artes e ciências... Feira de Santana: UEFS Editora, 2012, p. 15-21.

GIL, José. A imagem nua e as pequenas percepções: estética e metafenomenologia. Lisboa: Relógio D’ Água, 2005.

GODINHO, Ana. Diagramas para pensar/diagramas de sensação. In: GALLO, Silvio; NOVAES, Marcus; GUARIENTI, Laisa Blancy Oliveira (Orgs.). Conexões: Deleuze e políticas e resistências e... Petrópolis: DP\&A; Campinas: ALB; Brasília: Caés, 2013. 
O'SULLIVAN, Simon. From stuttering and stammering to the diagram: Deleuze, Bacon and contemporary art practice. Deleuze Studies, v. 03, n. 02. dez. 2009. Disponível em: <http://goo.gl/2eFO7s > . Acesso em: 31 mar. 2016. ISSN 1755-1684.

OLIVEIRA JÚNIOR, Wenceslao Machado. A rasura dos lugares - fragmentos espaciais reexistentes em vídeos. In: GALLO, Silvio; NOVAES, Marcus; GUARIENTI, Laisa Blancy Oliveira (Orgs.). Conexões: Deleuze e políticas e resistências e... Petrópolis: DP\&A; Campinas: ALB; Brasília: Caés, 2013.

OLIVEIRA JÚNIOR, Wenceslao Machado. Imagens desabam sobre paisagens - acidente e espaço acidental no cinema de Cao Guimarães. In: AZEVEDO, Ana Francisca ; RAMÍREZ, Rosa Cerarols; OLIVEIRA JÚNIOR, Wenceslao Machado (Orgs.). Intervalo II: entre geografias e cinemas. Braga: Universidade do Minho, 2015, p. 317-345. Disponível em: <http://goo.gl/iESbdc >. Acesso em: 20 fev. 2016.

RANCIÈRE, Jacques. A partilha do sensível: estética e política. Tradução de Mônica Costa Netto. São Paulo: 34, 2009.

RANCIÈRE, Jacques. O destino das imagens. Tradução de Mônica Costa Netto. Rio de Janeiro: Contraponto, 2012.

WUNDER, Alik; ROMAGUERA, Alda. Experimentações coletivas por entre poesias, fotografias e ventos-Áfricas. Informática na educação: Teoria \& Prática, Porto Alegre, RS, v. 17, n. 02, p. 31-45. jul./dez. 2014. Disponível em: <http://goo.gl/GHQYMD>. Acesso: em: 10 fev. 2016. ISSN 1982-1654.

WUNDER, Alik; ROMAGUERA, Alda. Experimentações coletivas por entre poesias, fotografias e ventos-áfricas. In: VOGT, Carlos et al. (Orgs.) Comunicação, divulgação e percepção pública de ciências e tecnologia. Petrópolis: De Petrus et Alii; Brasília: CAPES, 2003.

\section{ELENISE CRISTINA PIRES ANDRADE}

Doutora em Educação - UNICAMP, Campinas, SP - Brasil Professora do Departamento de Educação da Universidade Estadual de Feira de Santana UEFS, Feira de Santana, BA - Brasil - E-mail: nisebara@gmail.com

Recebido em: $31 / 03 / 2016$ Aprovado em: 11/05/2016.

\section{Como citar este documento:}

ANDRADE, Elenise Cristina Pires. Ocupações (im)prováveis: que cidade devém? ETD - Educação Temática Digital, Campinas, SP, v. 18, n. 3, p. 651-669, jul. 2016. ISSN 1676-2592. Disponível em: <http://periodicos.sbu.unicamp.br/ojs/index.php/etd/article/view/8644678 >. Acesso em: 30 ago. 2016. doi:http://dx.doi.org/10.20396/etd.v18i3.8644678. 